\title{
THE FACE OF EVIL The Muslim Beard Representation in Hollywood Movies in Post 9/11 Attacks
}

Received: 03/01/2020; Accepted: 09/05/2020

\begin{abstract}
Islam has been one of the highly misunderstood religions in the world. Many nonMuslim societies have never welcomed Islam. To Many Americans, the geographical imaginings of Arabs and Muslims are grounded on perceptions inherited from the Classical Orientalism that was established in Europe as a system of knowledge during the 18th and 19th centuries. Since the end of the Second World War, Americans have ornamented the early European prejudicial representation of Arabs and Muslims through constructing and disseminating essentialized and derogatory perceptions of this distinctive social group as inferior, backward, and dangerous 'Other'. Ever since the $9 / 11$ attacks and the escalation of the war on terror, images that successfully linked the Muslim bodily and religious practices with violence and terror gained great ascendancy in American mainstream media, popular culture, and political rhetoric. Focusing on the scale of the Muslim body, the present article probes the American motion picture industry (mainly Hollywood) representation of Muslim beard as a symbol of difference and danger in movies released in the post 9/11 attacks. Specifically, it examines beards as a bodily practice that supplies information about Muslims and as a key element used to breathe life into the reel bad Arab character in Hollywood movies. By focusing on Hollywood movies representations of bearded Muslim men, the article reveals how men's beards have been embedded in the discourse of fear, danger, and terror.

Keywords: Orientalism; Hollywood movies; post 9/11 attacks; the war on terror; Muslim men's beard.
\end{abstract}

Fatima Zohra MECHERI *

Department of letters and English Language

University of Frères Mentouri

Constantine 1,

Constantine, Algeria

\section{Résumé}

L'islam a été l'une des religions les plus mal comprises au monde. De nombreuses sociétés non musulmanes n'ont jamais accueilli l'islam. Pour de nombreux Américains, l'imagination géographique des Arabes et des Musulmans est fondée sur des perceptions héritées de l'orientalisme classique qui a été établi en Europe en tant que système de connaissances au cours des XVIIIe et XIXe siècles. Depuis la fin de la Seconde Guerre mondiale, les Américains ont orné la première représentation européenne préjudiciable des Arabes et des Musulmans en construisant et en diffusant des perceptions essentielles et désobligeantes de ce groupe social distinctif comme un «Autre» inférieur, arriéré et dangereux. Depuis les attentats du 11 septembre et l'escalade de la guerre contre le terrorisme, les images qui ont réussi à lier les pratiques corporelles et religieuses musulmanes à la violence et à la terreur ont acquis une grande importance dans les médias américains, la culture populaire et la rhétorique politique. Se concentrant sur l'échelle du corps musulman, le présent article examine la représentation de la barbe musulmane dans l'industrie cinématographique américaine (principalement Hollywood) comme symbole de différence et de danger dans les films sortis lors des attentats du 11 septembre. Plus précisément, il examine la barbe comme une pratique corporelle qui fournit des informations sur les musulmans et comme un élément clé utilisé pour insuffler la vie au mauvais personnage arabe dans les films hollywoodiens. En se concentrant sur les représentations des films hollywoodiens d'hommes musulmans barbus, l'article révèle comment la barbe des hommes a été intégrée dans le discours de la peur, du danger et de la terreur.

Mots clés orientalisme; les films hollywoodiens; les attentats du 11 septembre; la guerre contre le terrorisme ; la barbe musulmane.

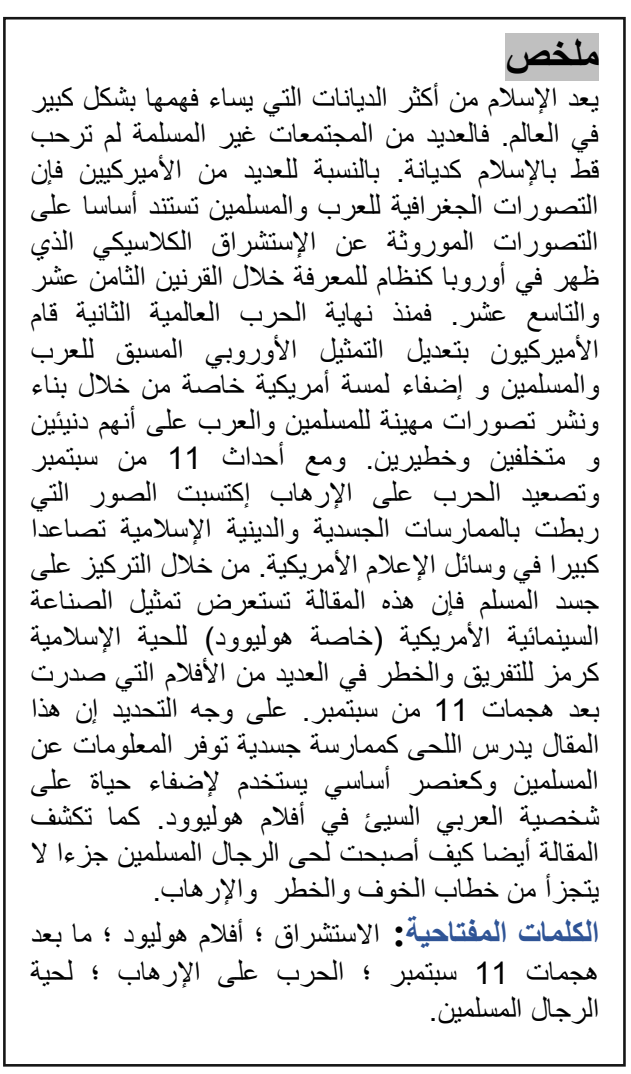

* Corresponding author, e-mail: mecheri.fatimazohra@yahoo.com 
"The Great enemy of the truth is very often not the lie -deliberate, continued and dishonest- but the myth, persistent, persuasive and unrealistic. Too often we hold fast to the clichés of our forebears" (qtd in Shaheen, Reel Bad Arabs 1)

President, John F. Kennedy

\section{Introduction}

The manner, in which Islam is understood in modern times in the Western world and mainly in the United States, is grounded on the imaginings and perceptions that were established by the $18^{\text {th }}$ and $19^{\text {th }}$ centuries European Orientalist scholars. Various studies have demonstrated that the American motion picture industry and mainly Hollywood attitude towards Islam, Muslims, and Arabs is inherited from the old school of Orientalism (known also as Classical Orientalism). Academics approved that Western knowledge of the Islamic world and its inhabitants was greatly motivated by the deeply held fear of Islam and Muslims, and was influenced by medieval age and colonial time prejudicial imaginings and visions. Using Orientalism as a system of knowledge, the Western world has constituted mythical boundaries that continuously has detached the Islamic world from the West, and helped define it through the notion of superiority versus inferiority and the crude thinking of the ' $u s$ versus them' as backward, primitive, and inferior 'Other' (Said, Orientalism 41-55-134-202; Sardar 124; Hourani 20-22; Esposito 20; Said, Covering Islam 4; Lockman 29; Turner, "Orientalism, or the Politics of the Text" 20-30; Vitkus 208-210; Hall and Gieben 298; Bhabha 3- 43; Semmerling 5; Al Djazairi 232-266; Little 9-42).

It is worth to mention that Western knowledge of the Islamic world was developed within the European imperial paradigm as a means to facilitate Western domination and exploitation of the Islamic world, while concurrently managing its hegemonic power over it. In Orientalism, Prof. Edward Said, from Columbia University, demonstrated that within the European traditional Orientalism, an assortment of images and symbols of the Muslim body contributed to the creation of the sloven, savage, and vicious 'Other'. Whether they were veiled women in a religious dress, sultry harem in exotic clothes, or even bearded ugly looking men, these images helped define Arabs and Muslims as inherently violent, oppressive, sex maniacs, primitive, dirty, lazy, religiously fanatic, and inferior 'other', who is in constant need of Western guidance and tutelage. Accordingly, this early European archive of knowledge, based on the direct contact with the Islamic world, has set the theoretical framework for modern day Western approach to Islam and Muslims. In the words of Semmerling, "Orientalism dominates the way that we in the West see, anticipate, and react to the Arab world in our past, today, and likely in the future" (Semmerling 5)

\section{American Orientalism}

By the end of the Second World War, the dismemberment of the European empires and the acceleration of decolonization around the world marked the emergence of the United States as the newly Western global superpower. However, Americans had very limited experience with the Orient in pre-WWII as it was a predominantly European colony. Prof. Edward Said asserted that the American geographical imaginings of Islam and Muslims is, majorly, based on abstractions and impressions accumulated from the American mainstream media and the political rhetoric (Palestine Diary). It was the threat of the red menace and the American deepening involvement in the Middle East, which entailed the American federal government to enlarge its pool of expertise in the region and beef up its knowledge of the Islamic world. Thus, by the 1960's the newly formed American Middle East institutions were headed and directed by foreign-born (European) academic experts, who migrated to the United States for the aim of informing the American public about the Islamic world, and benefiting the U.S. foreign policymakers and academia from the enormous European expertise on the Middle East (Lockman 111-122; Gerges 39; Said Orientalism 295; Pipes 8; Little 4852-194). The American geopolitical ascendancy necessitated the building of a much stronger national identity, and the acquisition of a leading position that would be appropriate for the new rising power, and the best way to do so was through the 
portrayal of foreign nations. From the 1960's until fairly recently, most Americans "relied on a well-defined hierarchy of race and culture in dealing with foreigners who looked and prayed differently" (Little 41).

As a European born nation, the United States of America allowed for the traditional European Orientalism to reassert its old vision into a new form, retaining the same old tenets of Classical Orientalism and continuously generalizing, essentializing, and derogating the Islamic world and Muslims. This European and American cultural industry that was built on the negation of the Islamic world has, for hundreds of years, shaped the Western discourse on Islam and Muslims. Douglas Little, an American historian, acknowledged that once the British Orientalist attitude made its way into the American government by the late 1940's, the Orientalist worldview of the Middle East invaded the American society and movie screens (Little 11). Using Orientalism as a theoretical framework for this inquiry is the appropriate way to understand Western imaginings and perceptions of Arabs and Muslims. It also offers the opportunity to see the Americans' image in the illusion of malicious Arabs. After all, Prof. Edward Said once alluded that Orientalism has less to do with the Islamic world than it does with the Western world (Said, Orientalism 12).

In the modern world, views of Islam as a fanatic religion that preaches violence, bigotry, fanaticism, and terrorism are omnipresent. Though irrational and terrorist acts can be carried by non-state actors or any radical individuals, viz., the Irish Republican Army, Taliban, veteran Timothy McVeigh, al-Qaeda, FIS, the ISIS, and plenty of others, sadly, it is Muslims and Arabs who are suspected most of the time for all of the irrational horrific acts (Shaheen, Reel Bad Arabs; Said, Covering Islam). One of the leading examples in this regard is the Oklahoma City Bombing 1995. The attack was undertaken by Timothy McVeigh, a U.S. Army veteran, and occurred two years after the first World Trade Center Bombing 1993 (an attack that was planned and executed by members of al-Qaeda terror network). Amidst the complete disorder and confusion ensued, American media readily suspected men of Middle Eastern appearance for the incident away before facts were confirmed, an act which unveiled eternal prejudice. Evidently, the term terrorism has unjustly become synonymous with Arabs and Muslims, thus, it reflects the faulty perception that most Americans and Westerners, in general, have of Islam as "The Green Menace" (Esposito 3) that continuously invokes fear and social apprehension. Fear of Islam has its roots lie deep into the past; it is since the seventh century that the Islamic threat has been the main cause of suspicion and hatred towards Muslims and the Islamic world.

By the mid-twentieth century, the emergence of oil as a major economic factor contributed to the raising power of the Middle East and exacerbated the geopolitical tensions in the region. Events such as, the Arab Israeli wars and the consequential Oil Embargo, the Iranian Revolution and subsequent Hostage Crisis, the Rushdie affair, the creation of the Palestinian Liberation Movement, Munich Olympics bombing 1972, the bombing of US Marines in Beirut in 1983, the hijacking of the TWA 847 in 1985, the first Gulf war 1990-1991, and the emergence of the Islamic militant groups, considerably facilitated the erroneous connection of Islam and Muslims to danger and terrorism. Fear of the 'Islamic Threat' (Halliday 107) became more pervasive by the end of the twentieth century. Islam was deemed the new global monolithic enemy number one of the Western world (Semmerling 202; Esposito 3; Shaheen, Reel Bad Arabs 2; Marrison; Suleiman 35). Immediately, views of Muslims as fanatic, bigotry, morally evil, bloodthirsty, inherently violent, anti-American, aggressive, and the list goes on, gained a considerable ascendancy in American media. Simply put, terms like 'Arab' or 'Muslim' have stood for a potential threat for most Americans, who had the tendency to falsely conflate the diversity of Arabs and Muslims and project them as a homogeneous blob (Shaheen, Guilty iii). Michael Suleiman in an article entitled "Islam, Muslims, and Arabs in America: the Other of the Other of the Other..." argued that "Americans rarely distinguish between Muslims and Arabs, and view both of these groups as alien to themselves as well as to Western heritage" (Suleiman 33). American fear and feeling of impotence towards Islam and Muslims brought about sweeping generalizations that have easily engulfed the whole diversity of Arabs and Muslims into the image of the terrorist 'Other'. The American biased knowledge, its essentialism, its generalization, and its conflation is, indeed, the eternal bequest of the 
European Classical Orientalism that was inherited by Americans upon the geographical shift in the source of Orientalism following WWII. That is to say, though the Orientalist discourse has undergone major changes since it was first established as a system of knowledge in the eighteenth and nineteenth centuries, it has retained its principle dogmas.

Orientalist essays helped engender a common and solid belief that Muslims and Arabs are the West's number one enemy. Arabs and Muslims image in Western media has been highly disfigured by anti-Muslim Orientalists such as, Daniel Pipes, Khalid Duran, Judith Miller, Martin Peretz, Bernard Lewis, and others. Their numerous articles and essays have been obsessed with Muslim/Arab hatred and helped broadly disseminate images of devilish Islam, Arabs, and Muslims in the West. One example of the worst offenders against Islam and Muslims is the British historian and the retired Princeton Professor, Bernard Lewis. In his article to The Atlantic Monthly magazine entitled "The Roots of Muslim Rage" published in September 1990; he endorsed the 'Clash of Civilization' theory that was later adopted and expended by Samuel Huntington in his article "The Clash of Civilizations?" to the Foreign Affairs magazine. Lewis suggested that the Islamic world was not only violent, oppressive, and utterly different from the Western world, but it was on the verge of a clash with the West and its values and ideologies. This Orientalist article not only conflates rage with Muslims, but also suggests that violence is deeply rooted and constitutes an integral part and a natural aspect of the Islamic mind. Published on the front page of the magazine, a pictorial image that accompanied Lewis's article, in which a turbaned, bearded man with his eyes reflecting the American flag sums up the article's content, and suggests that the inborn Muslim rage is straightly intended for the United States. Bernard Lewis's article and its accompanied pictorial image on The Atlantic Monthly magazine are but a mere example of plenty of other Orientalist articles and images that openly suggest and endorse the perception that Islam is a violent religion, and its adherents are innately dangerous, violent, and threatening. John Esposito, Georgetown University academic, once stated that "the academic Orientalists, U.S. policymakers, and the American media had, like twentieth century Scheherazade, conjured up the genie of rampaging "Islamic Fundamentalism" to fill a "threat vacuum" created by the collapse of the Soviet Union and the end of the Cold War" (qtd in Little 36).

As the twenty-first century embarked on, the 9/11 terrorist attacks seemed to verify Bernard Lewis and Samuel Huntington 'Clash of Civilizations' theory. What the Western world regarded as the re-emergence of "The Green Menace" following the collapse of Soviet Communism seemed to overwhelm the West. The American Orientalism style that was developed within the Cold War paradigm metamorphosed into a new form that operated within the 'War on Terror' paradigm known as the 'neoOrientalism' (Behdad and Williams). This new form of Orientalism had the tendency to conflate Islam, Arabs, and Muslims with terrorism. By almost any measure of outcome, the very frequent U.S. media portrayal of horrific acts committed by what is often called the Islamic militants, terrorists, or radical Islamists influenced considerably the American perceptions of the Muslim 'Other'.

\section{An Introduction to Beard}

Beard has stood for manifold meanings in various societies over time. It is defined as the unique natural masculine feature that distinguishes males from females (as it grows at a certain age) and a bodily practice that supplies information about the individual's identity (Gole 810; Firth 285; Al Makki 100). Anthropologists and psychologists argued that the beard has various implications and it is worn for several reasons ranging from medical and cultural to spiritual and even political (Gowing 6). Nonetheless, the beard plays an important role in forming the peoples' perception about manhood. Scholars argue that the beard can stand for manliness, strength, completeness, dignity, muscularity, fertility, personal power (Gowing 6; Delaney 168; Peterkin 92; Oldstone-Moore 2-92-188-189-225) and "it is said to perfect the natural characteristics of the man" (Al Makki 100). And can also be a symbol of filthiness, 
danger, and backwardness (Leach 149). Lately, beards are regarded as something that hides the true face of malevolent men.

Religiously speaking, beard has had a great significance in various religions. Within Islam, for instance, though there exist no instructions on facial hair in the Holy Qur'an, Muslim men retain their beards out of love, respect, and obedience to their Prophet Mohammed (PBUH). Keeping facial hair is a habit that is deeply entrenched within certain Muslim societies and it is in the traditional Islam, according to scholar Gaffney, "a mark of authority and piety" (Gaffney 56).

Scholar De Sondy once argued, in his article "The Relationship between Muslim Men and their Beard in a Tangled One", that the beard is a defining visual aspect of Islam (De Sondy), and in "The Voluntary Adoption of Islamic Stigma Symbols", writer Gole regarded facial hair as a religious symbol that in wearing, individuals are "overtly identifiable as Muslims and publically assertive" (Gole 816). But regarding the beard as a defining visual aspect of Islam conceals the great significance that it had in various civilizations and religions (Sikhism, Judaism, Christianity, Hinduism, and Buddhism). Besides, Muslim beard is a habit (Sunna) that men respectfully follow and does not necessary define Muslim men. Regardless of the ethnic background, beard can sometimes be kept out of a cultural or political commitment, or even as a personal or a style choice. From Abraham Lincoln and Harvard University elites during 1870's (Peterkin 36-38) to present day famous athletes, models, and actors, beards stood for manliness, authority, and piety. That is to say, beards are kept for several reasons and are not possibly signs of one's culture or a reference to one's religious identity.

Within the Orientalist discourse, the beard has for centuries been equated either with backwardness or non-Western people. It is considered as a very powerful bodily symbol that evokes fear and its removal has been a sign of modernization and westernization. Kemal Ataturk and his modern day Turkey and Peter the Great in Russia offer two excellent examples in this regard. By the late seventeenth and early eighteenth centuries, Peter the Great in Russia ordered Russian males to shave their beards in order to westernize (Gowing 7). Likewise, following the First World War, Ataturk encouraged Turkish males to abandon their facial hair and adopt Western styledress as a move toward liberalization and modernization (Kadioğlu 191). Physical appearance, Western style-dress and clean-shaven face, has always been regarded as central to modernization and they remain so today. If one takes a close look into the Algerian society under the rule of the French colonialism, he/she can clearly see that the natives who came to a close contact with the French settlers, dressed and talked similarly, were regarded as secular and inoffensive. Many societies have instituted reforms to westernize throughout the years and even though a large number of men retain their beards for a multitude of reasons, the association of beard with backwardness is still common.

\section{Hollywood Representation of Muslim Beards}

Orientalist intellectuals, politicians, travelers, and mass media mutually helped to construct and perpetuate Orientalist representations of Muslims in the United States. Allegedly, since the end of the Second World War, the American mainstream media played the most pivotal role given the huge influence it exercises over its audience. This paper focuses on the American media of entertainment (Hollywood), by dint of its wide range and the central role it plays in shaping, presenting, and disseminating negative perceptions about Arabs and Muslims, and in conjuring up that mythical link of Muslim beard to danger. American Hollywood is regarded as the world's greatest entertainer and the most effective teacher of younger generation. For years, since its early creation, Hollywood has tutored the American youngsters various things and shaped their thoughts and beliefs. Lately, the American motion picture industry became a powerful cultural force and the most dominant source of information about distinct places and cultures. Though Hollywood had the tendency to stereotype and demonize various racial and ethnic groups over time, its representation of Arabs, Muslims, and Middle Easterners is oversimplified and malignant. On the silver screen, academics regarded Hollywood representation of Arabs and Muslim as prejudicial and worth of critical academic scrutiny. This article's critique of Hollywood's use of beard to 
symbolize the vicious 'other' begins with a review of the major determinants that influenced Hollywood movie stories and have perpetuated the perception that Islam is a religion to be feared, then, provides insights into Hollywood's representation of the Muslim beard in post 9/11attacks.

When tracing the roots of misconception, academic scholars argued that numerous factors have contributed to the creation and perpetuation of negative portrayal of Arabs and Muslims in Hollywood movies. While some of these factors could be offset, others are so deeply embedded within the American culture that there exists no possible end to them. Hollywood's bigotry representation of Arabs/Muslims has been profoundly discussed in various scholarly works. Jack Shaheen and his contemporaries' meticulously documented researches into the film and motion picture industry have helped to highlight the dehumanizing personification that moviemakers have given to Arabs and Muslims. A profusion of valuable academic works from books and articles to lectures, essays, and op-eds have identified what is regarded as the leading determinants of Hollywood negative personification of Arabs and Muslims.

It is worth to note that the Islamic world has for decades been portrayed through the thick haze of Orientalism (Khleif 281). Early European Orientalism provided the material for the representation of the Islamic world as a place of wonder, fantasy, mystery, luxury life, lamp genies, with flying carpets and magic lanterns inhabited by corrupt, barbaric, lazy, bearded, ugly looking, wicked viziers, slimy slavers, irreverent magicians and vicious Arabs/Muslims, harem maidens, and oppressed females, who constituted the West's cultural 'Other'. These fictional renditions of the brutal 'other' were accepted as valid and adopted by filmmakers to a degree that it became such indelible part of Hollywood representation of Arabs. Hollywood moviemakers came to consistently lambaste Arabs, Muslims, and Middle Easterners on silver screen for over a century. Arabs were identified as America's public enemy number one and were frequently depicted as the eccentric and intimidating 'other' in various movies (Said, Orientalism 59; Shaheen, Reel Bad Arabs 2; Shaheen, The TV Arab 13).

Ever since the camera began cranking, Hollywood had the tendency to inaccurately and prejudicially represent distinct racial and ethnic groups over time (Shaheen, "Hollywood's Muslim Arabs" 25; Michalak 33). Yet, by the time Hollywood was progressively abolishing bigoted portraits of other group it has been fascinated with the Arab negative character. Recently, Arabs and Muslims are the most highly misunderstood, vilified, and malignant group in American cinema. Hollywood attitude towards Arabs and Muslims is deemed intolerant and dogmatic. James Baerg, the director of program practices for the CBS-TV in New York City, explained "the Arab stereotype is attractive to a number of people. It is an easy thing to do. It is the thing that is going to be most readily accepted by a large number of audiences. It is the same thing as throwing in sex and violence when the episode is slaw" (qtd in Shaheen, "Hollywood's Muslim Arabs" 23).

Within the early Hollywood movie portrayal of Arabs, filmmakers constructed a mythical Arab land composed of desolate deserts, oasis, palm trees, slimy souks, flying carpets, and corrupt places. Complemented by 'An Instant Ali Baba Kits' made of magic lamps and lanterns, seen through pantaloons, veils, jewellery, fake beards and mustaches, exaggerated noses, curved daggers, scimitars, and burnooses (Shaheen, Reel Bad Arabs 8). These elements were used to successfully formulate the classical representation of the Arabian fantasy in movies.

Jack Shaheen, Professor of Emeritus of Mass Communications at Southern Illinois University, is one of the most prominent scholars who established an entire new field of study known as 'Arab-American Media Studies'. Through his scrutiny of cinema texts, Jack Shaheen found that only little had been written on American media portrayal of Arabs and Muslims. It is truism that the field of 'Arab-American media studies' is still very young for the motion picture industry is only little over a century old. However, two of his groundbreaking books ('Reel Bad Arabs' (2001) and 'The TV Arab' (1984)) laid a framework of reference for the newly constructed field of study.

In his book Reel Bad Arabs: How Hollywood Vilifies People (2001), Jack Shaheen, driven by the huge need to expose the slanderous history of the Arabs' 
representation in the American motion pictures industry, has conducted a research study in which he scrutinized more than 900 movies released from 1896 to 2001 . He unfolded decades of harmful stereotypes that rendered the Islamic world a place to be feared with inhabitant who were "brute murderers, sleazy rapists, religious fanatics, oilrich dimwits, and abusers of women" (Shaheen, Reel Bad Arabs 2). These negative portraits of Arabs in countless movies stoked distrust and loathing towards Arabs and Muslims in American society. Quoting President John F. Kennedy's statement that "The Great enemy of the truth is very often not the lie -deliberate, continued and dishonest- but the myth, persistent, persuasive and unrealistic" (qtd in Shaheen, The TV Arab 13) in his book The TV Arab (1984), Jack Shaheen acknowledged that the American TV tends to perpetuate four basic myths about Arabs as: "they are all fabulously wealthy; they are barbaric and uncultured; they are sex maniacs with a penchant for white slavery; and they revel in acts of terrorism" (Shaheen, The TV Arab 4). It is these myths, argues El-Ferra, which "often inspire directors, producers and screenwriters to develop a product which is then based on stereotypes" (El-Ferra 4-5).

Actually, the widely alienating visual vilification of Arabs and Muslims has been a predominant part of the Hollywood moviemaking process. Contemporary moviemakers have not only inherited but further ornamented the European pre-existing Arab stereotypes and misconceptions. "The Muslim Arab continues to surface as the threatening cultural 'Other" (Shaheen, "Hollywood's Muslim Arabs" 23) in various movies. Through using the Arabic proverb 'Al tikrar biallem il hmar' (translated in English as 'By repetition even the donkey learns'), Jack Shaheen asserted that motion picture industry for over a decade repeatedly reinforced over and over again the same old Orientalist stereotypes that were presented in literature, art, and academic works (Shaheen, Reel Bad Arabs 1).

"Pause and visualize the reel bad Arab. What do you see? Black beard, headdress, dark sunglasses" (Shaheen, Reel bad Arabs 2), Jack Shaheen's statement demonstrates that Hollywood blockbusters have relentlessly used the Arab dark beard and costumes to create the reel bad Arab characters in movies. Thus, characters who played the bad Arabs shared the same menacing look and the same character traits. They were dressed differently most of the time in Arabic traditional garb or in nomadic and peasants clothing, turbaned, hooded, with hooked noses and fake dark long beards and dark sunglasses. The reason behind is to offer that cruel image of an ugly looking vicious Arab who is bent on destroying America. This image of Arabs as the bad-guys was omnipresent in Hollywood movies since the camera began cranking. The Muslim man was given fanatical and barbaric characteristics in Hollywood movies to create a well-known image of a terrorist. Being casted in that negative light, Arabs and Muslims were placed in a category that most Americans understood and were familiar with. Within this framework, Muslim beard, which is regarded by some Muslims as a bodily symbol worn by elderly man of wisdom or religious leaders and which signifies manliness, masculinity, authority, and piety (Firth 285; Gaffney 56) (at least to Muslims) was regarded as a sign of backwardness, savageness, and filthiness in the West.

News media headlines and printed media Orientalist articles have had a powerful role in the creation and the dissemination of negative stereotypes about Arabs and Muslims as violent and dangerous. Headlines and articles influence moviemakers' opinions and beliefs and inspire their movie storylines. Stressing the huge influence of American news media on movies, Jack Shaheen argued “"if it bleeds it leads" news reports" (Shaheen, Reel Bad Arabs 28) continue to influence Hollywood production. As ordinary Americans, moviemakers' opinions and perceptions are formed on the basis of what they read, hear, and see on the news media. Bustany and Al- Marayati, quoted in "Reverse Imagery Middle Eastern Themes in Hollywood" by Rebecca Stone, argued "the image- the false image- held by most Americans is the result of selective reporting by the news media, ... which is then exploited by entertainment media (because movies need villains). That's how we, and our kids, learn what Arabs and Muslims look like and how they behave" (qtd in Stone 259).

In The TV Arab (1984), Jerome Stanley, NBC's vice president for broadcasts standards, responded to Shaheen's question "why Arabs are "fair game"" arguing "I don't think one can point the finger at television and television alone. Television 
entertainment producers, like news reporters, sometimes take their information from newspaper headlines, editorial cartoons and articles in magazines rather than generate the information themselves" (qtd in Shaheen, The TV Arab 6). The continuous flow of "seen one, seen'em all" headlines and misrepresentations in Orientalist articles have in a kind filtered down to filmmakers and network producers. Stanley believed that news media information became "a part of one's philosophy" (qtd in Shaheen, The TV Arab 6 ) and the net result is an anti-Arab scenario imbued with stereotypical representation of Arabs and Muslims.

The continuous news media representation of Arabs and Muslims as villains acts as both a source and a ploy for the permanent filmmakers tarnishing of Arabs/Muslims' image in movies, thus, not only impacts the American perception about this distinctive social group, but also reinforces and solidifies the already existing and pervade stereotypes. Filmmakers would rather objet "we're not stereotyping" "just look at your television set. Those are real Arabs" (Shaheen, Reel Bad Arabs 29).

According to Evelyn Alsultany "Demonizing the enemy is so common during times of war" (Alsultany 2), from the early years of the American campaign against native Americans, to Japanese during WWII, Russians during the Cold War, and lately Arabs since the first Gulf War 1991, the 'Other' had been represented as a barbaric menace. Hollywood had the tendency to portray them as sub-human and malevolent. The choice of villain in American movies is dictated by headlines and events that attract the public interest, movies are reflections of real life, (Shaheen, The TV Arab 11), which explains why Arabs and Muslims are the villains of choice since the late part of the twentieth century. They are the latest ethnic group that is casted in stereotypical bad-guy roles in American cinema since the fall of the Soviet Communism (Semmerling 4; Shaheen, "The Hollywood Arab: 1984-1986” 148).

As the twentieth century drew to its end, the emergence of the Islamic militant groups and Osama bin Laden's declaration of war on the United States troubled the American government and received wide-spread media attention. The increase of violent attacks and verbal threats against the Western world by non-state Islamic militant groups heightened the suspicion of Muslim/Arabs for all the heinous crimes, mass destruction, surprise attacks, hijacking death, brutal violence, and terrorism. Under the strict Islamic rule of the newly formed Islamic militant groups, the beard became a symbol of a devout Muslim. The American political discourse during this period culminated the growing hostility against Arabs, Muslims and people who look alike (Sikhs for instance). Essentially, the enduring visual representation of the Taliban and the al-Qaeda leaders and their symbolic beards as icons of affiliation with the Islamic extremist groups in nightly news footage, magazines, showed pictures of militant Muslims, and printed (in) famous, informative articles illustrated the strong connection between Muslim beard and danger. This demonstration was accessible to moviemakers who turned to headlines for inspiration and story material. Hence, late twentieth century Hollywood production successfully linked the Islamic religion, the religious and bodily practices (such as, prayers, beards for men, and veils for women) with men's oppression, Holy war (Jihad), violent acts, hostility and hatred towards the Western civilization, peace, and democracy. Hollywood portrayal of Muslim beard not only sustained the Orientalist antiquated discourse of beard as a symbol of backwardness but further associated it with terror and danger.

Within the Orientalist discourse, the beard became a powerful symbol that frequently invokes fears and social anxiety. During the 1980's, in Turkey, for instance, Muslim men were forbidden to let their beards grow. Beards were conceived as symbols of affiliation with the militant groups who threatened the order of the state (Delaney 168). Much similar in Algeria during the 1990's people chose to shave their beards in order to avoid social consequences and meanings of beards. Western media discourse focused on the Muslim beard as a symbol of Islamic extremism, radicalism, and dangerous 'Other'. In Hollywood, the beard became an important component to successfully breathe life into that cruel and villain image of the bad Arab making the potential terrorist. In the words of Yousef Salem, a former spokesman for California's South Bay Islamic Association, "All the bad guys have beards and large bulbous noses, 
sinister eyes and heavy accents, and they're wielding swards constantly" (qtd in Shaheen, Reel Bad Arabs 52)

In view of what happened on that infamous Tuesday, September $11^{\text {th }}, 2001$. Arabs and Muslims undeniably proved themselves to be the real America's enemies. The attacks provided another reason to further vilify Arabs and Muslims on the silver screen. Hollywood prejudicial representation of Arabs and Muslims became more insidious following the $9 / 11$ attacks, as they met the least resistance and were vigorously defended and accepted as truth. Sweeping mischaracterizations and stereotypes equated Arabs and Muslims to violence and terrorism. This distinctive social group continues to be portrayed in pejorative terms as the threatening cultural 'Other' who earned the American prejudicial ire. Following the 9/11 events and the escalation of the 'War on Terror' campaign, moviemakers and TV producers embellished the early familiar stereotypes with new more malicious typecasts which further downgraded Muslims and Arabs and increased anti-Muslim prejudice. That is to say, then and now Arab characters are carefully crafted to alarm the viewers and impact the perception of the whole Hollywood audience.

Incidentally, Muslim men's beard in popular imagination were reduced to simple mask worn by terrorists in order to hide their "faces of evil" (to borrow from CNN anchor woman Paula Zahn) (qtd in Semmerling 202), and was in this regard, denied of its religious and cultural value. Hidden behind their beards, in movies, Muslim men are equated to disguised jihadists, evil doers, and savage persons. That is how, in the word of Faiq Najeeb for the Express Tribune Blog, "sinning souls of militant Islamists tarnished the image of the beard which was once the symbol of a pure mo'min (believer of Islam)" (Najeeb). Muslim Beard's analogy to terrorism and extremism in movies released following the 9/11 attacks helped cultivate roots of an evil Arab character (Andreou; Brah 275). As it is demonstrated in most of post $9 / 11$ attacks Hollywood released movies and series including Click (2006), Criminal Minds (2007), Fatwa (2006) Jackass Number Two (2006), Sorry Haters (2006), and others.

Perceptibly, the beard as a symbol of backwardness, savageness, filthiness, and lately as a sign of affiliation with terror groups in Hollywood movies is confined to Muslim beard. Beards once worn by Westerners in movies do not have that analogy to terror. Today, though beards are the latest male grooming trends, wearing a beard is still regarded as a bodily practice that supplies information about Muslims. Westerners willingly relate beards to the Islamic identity regardless of the reasonable size of Muslim men who do not wear beards. In the West, growing a beard is a personal choice which is tolerated as long as it is not worn by a Muslim man. Beards, once worn by Muslim men, arouse suspicion as they became signs of extremism, danger, and terror. That is to say, the major problem is not beard as worn by any man regardless of his religious or cultural background, but it is the perception that most Westerners have accumulated, over centuries, in regard to beards worn by Muslim men. This suggests that Muslim men can never enjoy the same physical freedom as their European or American counterparts (Fahd; De Sondy).

In sum, the manner in which Arabs and Muslims are represented in America from scholarly textbooks to Hollywood movies proves that the American version of Orientalism had come to implant deep roots into the American popular culture (Little 11). The incessant dehumanization of Muslims and Arabs provides a vantage point to see Americans' image in the illusion of the evil Arab as the moderate "good guys" fighting against "bad guys" for freedom and peace. 


\section{Conclusion}

Human being bodily practices, whether veils for women or beards for men, are regarded as sites, where identities are created and are publically assertive. Despite the fact that the beard has stood for an array of meanings and implications and has had a great significance in different civilizations and religions for centuries, yet, since the eighteenth century it become a symbol of backwardness, filthiness, savageness, and its removal was regarded as a sign of liberation, westernization, and modernization.

The Orientalist representation of the Muslim beard was carefully transmitted to Hollywood movies. In Hollywood, the Muslim Arab character can never be complete without the traditional Arab costume and the fake facial hair costume accessories. Costumers and makeup artists cleverly dress actors who play the reel bad Arab in Arab traditional clothes (robes and turbans), and in fake dark long beards to successfully form the bad Arab character image that is commonly held by the general audience. Rather than trying to accurately represent the millions of good Arabs and Muslims in movies, and challenge the commonly held perceptions about Muslims/Arabs as violent and terrorists, Hollywood moviemakers further reinforce the flaw imaginings inculcated in the American society. Since the 1980's, the Muslim beard, undoubtedly a symbol of affiliation with terror groups, has been used by Hollywood blockbusters repeatedly over and over again to successfully feature the mythical link between the Muslim beard and terrorism.

The news media headlines and printed Orientalist articles have had a powerful role in creating and disseminating negative stereotypes about Arabs and Muslims as violent and dangerous. They have been influencing moviemakers' opinions and beliefs and inspiring their storylines. Therefore, following the 9/11 attacks Hollywood featured Arabs/Muslims as associated with heinous acts of mass destruction, hijacking, and killing of innocent people in various movies.

The Hollywood tendency to ignore the diverse identities of Arabs, Muslims, and Middle Easterners, and lump them all together in association with terrorism, has had direct implications on the general audience. Americans form their geographical imaginations on the basis of what the American mass media project. In the words of Jack Shaheen

"We are taught to hate them [Arabs and Muslims]. It comes from the fictional bombardment of media images. It comes from what our media teaches us. Movies teach us who we should love and who we should hate. 150 centuries have been taught to hate everything that is Arab and Muslim. The longer it continues without being contradicted the more opportunity there is for men and women to be hurt. There is tremendous fear in the Arab community. If your name's Hussein, change it to Harry" (qtd in Marrison)

Hollywood enduring connection of Muslim beard with terrorism perpetuated the discourse of the dangerous 'Other' across the globe. Since 9/11, the discrimination of bearded men, mistakenly associated with Islamic militant groups, has been on the rise in the United States and in Europe. Jack Shaheen reminds us that "when one ethnic, racial, or religious group is vilified, innocent people suffer" (Shaheen, Reel Bad Arabs 4). Indeed, the connection between beards and violence was omnipresent and openly shown to the general public through the American mass media (whether entertainment or information media). Muslim men had to shave off their beards to avoid being falsely mistaken as terrorists particularly in Europe and America. To conclude, it is pertinent to ponder the words of Plato in this respect "Those who tell the stories also rule society" (qtd in Shaheen, Reel Bad Arabs 5) 


\section{References}

[1]. Al Djazairi, Salah Eddine. The Myth of Muslim Barbarism and its Aim. Bayt Al-Hikma Press, n.d. PDF file.

[2]. Al Makki, Abu Talib. "The Beard." Muslim World 68.2 (1978): 100-118. PDF file.

[3]. Alsultany, Evelyn. Arabs and Muslims in the Media race and representation after 9/11. New York : Newyork University Press, 2012. PDF file.

[4]. Andreou, Alex. "How Growing a Beard made me 'a terrorist'." The Guardian (2013). Web. 15 November 2018.

<https://www.theguardian.com/commentisfree/2013/jun/03/day-i-became-aterrorist>

[5]. BIBLIOGRAPHY \l 1036 Behdad, Ali and Juliet A. Williams. 2012. THE STATE OF 'IN-BETWEEN' IN CONTEMPORARY IRANIAN ART. 01 June 2017. <http://www.entekhabi.org/Texts/Neo_Orientalism_Today.htm>.

[6]. Bhabha, Homi K. The Location of Culture. London: Routledge, 1994. PDF file.

[7]. Brah, Avtar. "Articulations Across Diaspora, Law and Literature." Diaspora, Law and Literature. Ed. Klaus and Carpi, Daniela Stierstorfer. Vol. 12. Library of Congress, 2017. 273- 292. Google Books. Web. 05 November 2017.

[8]. Delaney, Carol. "Untangling the Meaning of Hair in Turkish Society." Anthropological Quarterly 67.4 (1994): 159-172. PDF file.

[9]. De Sondy, Amanullah. "The Relationship Between Muslim Men and their Beards is a tangled one." The Guardian (2016). Web. 26 December 2017. <https://www.theguardian.com/commentisfree/2016/jan/28/muslim-menbeards-facial-hair-islam>

[10]. El-Ferra, Narmeen. "ARABS AND THE MEDIA." Journal of Media Psychology 1.2 (1996). PDF file.

[11]. Esposito, John L. The Islamic Threat: Myth or Reality? Third Edition. New York: Oxford University Press, 1992. Internet Archive: Digital Library of Free Books, Movies, Music and Way back Machine. Web. 20 September 2016.

[12]. $\quad$ Fahd, Cherine. "The Assumptions People Make About Dark Bearded Men." The Sydney Morning Herald (n.d.). Web. 10 December 2017.

<http://www.smh.com.au/comment/the-assumptions-people-make-about-darkbearded-men-20170405-gveoy4.html>

[13]. Firth, Raymond. Symbols: Public and Private. Ithaca NY: Cornell University Press, 1973. Internet Archive: Digital Library of Free Books, Movies, Music and Way back Machine. Web. 16 March 2017.

[14]. Gaffney, Patrick. Shaykh, Khutba and Masjid: the Role of the Local Islamic Preacher in Upper Egypt. PhD Dissertation. University of Chicago, 1982. PDF file.

[15]. Gerges, Fawaz A. «Islam and Muslims in the Mind of America: Infleunces on the Making of US Policy.» Journal of Palestine Studies 26.2 (Winter1997): 68-80. PDF file.

[16]. Gole, Nilufer. "The Voluntary Adobtion of Islamic Stigma Symbols." Sicial Research 70.3 (2003): 809-828. PDF file.

[17]. Gowing, Thomas. The Philosophy of Beards: a Lecture: Physiological, Artistic and Historical . n.d. Internet Archive: Digital Library of Free Books, Movies, Music and Way back Machine. Web. 13 December 2017.

[18]. Hall, Stuart and Gieben, Bram, ed. Formation of Modernity. Great Britain: Open University, 1992. PDF file.

[19]. Halliday, Fred. Islam and the Myth of Confrontation: Religion and Politics in the Middle East. London: I.B. Tauris, 1999. Internet Archive: 
Digital Library of Free Books, Movies, Music and Way back Machine. Web. 20 Mai 2017.

[20]. Hourani, Albert. Europe and the Middle East. California: University of California Press, 1980. Google Books. Web. 20 April 2017.

[21]. BIBLIOGRAPHY I 1036 Huntington, Samuel. "Clash of Civilization?" Foreign Affairs (1993): 22-49. PDF file.

[22]. Kadioğlu, Ayşe. "The Paradox of Turkish Nationalism and the Construction of Official Identity." Middle Eastern Studies 32.2 (1996): 177193. PDF file.

[23]. Khleif, Bud. "Distortion of "Islam" and "Muslims" in American Academic Discourse: Some Observations on The Sociology of Vested Enmity." In Cultural Diversity and The US Media. Ed. Kamalipour.Y and Carilli.T. New York: State University of New York Press, 1998. 279. Google Books. Web. 20 March 2015.

[24]. $\quad$ Leach, E.R. "Magical Hair." Journal of the Royal Anthropological institute 88 (n.d.): 147-164. PDF file.

[25]. Lewis, Bernard. "The Roots of Muslim Rage." Atlantic Monthly 266.3 (1990): 47-60. PDF file.

[26]. Little, Douglas. American Orientalism: The United States and The Middle East since 1945. Chapel Hill: The University of North Carolina Press, 2002. Internet Archive: Digital Library of Free Books, Movies, Music and Way back Machine. Web. 20 November 2016.

[27]. Lockman, Zachary. Contending Visions of the Middle East: the History and Politics of Orientalim. Second Edition. Cambridge: Cambridge University Press, 2010. PDF file.

[28]. Mandel, Daniel. "Muslims On The Silver Screen." The Middle East Quarterly 8.2 (2001). Web. 15 September 2016.

$<$ HYPERLINK "https://www.meforum.org/articles/other/muslims-on-thesilver-screen

" https://www.meforum.org/articles/other/muslims-on-the-silver-screen >

[29]. Marrison, James. "Arabs Not The First To Be Blown By The Movie." Afterimage 31.5 (2004). PDF file.

[30]. Michalak, Laurence. "Cruel and Unusual: Negative Images of Arabs in Popular American Culture." American Arab Anti-Discrimination Committee 3.15 (1988). PDF file.

[31]. Najeeb, Faiq. "Beards Are Not Just For Terrorists." The Express Tribune (2011). Web. 21 December 2017.

<https://blogs.tribune.com.pk/story/4138/beards-are-not-just-for-terrorists/>

[32]. Oldstone-Moore, Christopher. Of Beards and Men: The Revealing History of Facial Hair. Chicago and London: The University of Chicago Press, 2016. Google Books. Web. 17 December 2017.

[33]. Peterkin, Allan. One Thousand Beards: A Cultural History of Facial Hair. Vancauver: Arsenal Pulp Press, 2001. Google Books. Web. 06 December 2017.

[34]. Pipes, Daniel. "Understanding Islam in Politics." Pipes, Daniel. In the Path of God: Islam and Political Power. fifth. New Brunswick: Transaction Publishers, 2009. 3- 25. Google Books. Web. 24 November 2017.

[35]. Said, Edward W. Covering Islam: How the Media and the Experts Determine How we See the Rest of the World. New York: Vintage Books, 1997. Internet Archive: Digital Library of Free Books, Movies, Music and Way back Machine. Web. 20 November 2016.

[36]. - Orientalism: Western conceptions of the Orient. London Penguin, 1978. PDF file.

[37]. Sardar, Ziauddin. Concepts in the Social Sciences Orientalism. Buckingham Pheladelphia: Open University Press , 1999. PDF file. 
[38]. Semmerling, Tim Jon. Evil Arabs in American Popular Film: Orientalist Fear. Austin: University of Texas Press, 2006. Google Books. Web. 20 November 2017.

[39]. Shaheen, Jack. Guilty: Hollywood's Verdict on Arabs After 9/11. Northhampton Massachusetts : Olive Branch Press, 2008. Google Books. Web. 10 October 2017.

[40]. ㄴ. "Hollywood's Muslim Arab." The Muslim World (2000): 22-42. PDF file.

[41]. -. Reel Bad Arabs: How Hollywood Vilifies a People. Northhampton, Massachusetts : Olive Branch Press, 2001. Internet Archive: Digital Library of Free Books, Movies, Music and Way back Machine. Web. 01 November 2017.

[42]. _ - "The Hollywood Arab: 1984-1986" Journal of Popular Film and Television (1987): 148. PDF file.

[43]. - The TV Arab. Bowling Green, Ohio: Bowling Green state University Press, 1984. PDF file.

[44]. Stone, Rebecca. "Reverce Imagery: Middle Eastern Theme in Hollywood." In Images Enchantment: Visual and Performing Arts of the Middle East. Ed. Sherifa Zuhur. Cairo: The American University in Ciaro Press, 1998. 247-263. Internet Archive: Digital Library of Free Books, Movies, Music and Way back Machine. Web. 01 December 2017.

[45]. Suleiman, Michael. «Islam, Muslims and Arabs in America: The Other of The Other of The Other...» Journal of Muslim Minority Affairs 19.1 (1999): 33-47. PDF file.

[46]. Turner, Bryan S. Orientalism, Postmodernism, and Globalism. London and New York: Routledge, 1994. Google Books. Web. 10 June 2015.

[47]. Vitkus, Daniel J. "Early Modern Orientalism: Representations of Islam in Sixteenth and Seventeenth Century Europe." Western Views of Islam in Medieval and Early Modern Europe: Perception of Other. Ed. David R. Blanks and Michael Frassetto. New York: St Martin's Press, 1999. PDF file. 